\title{
Characterization of L-Aspartate Uptake by Streptomyces hydrogenans
}

\author{
By KLAUS RING, WERNER GROSS, HELLA EHLE \\ AND BEATE FOIT \\ Abteilung für Mikrobiologische Chemie, Gustav-Embden-Zentrum der Biologischen \\ Chemie, Johann-Wolfgang-Goethe Universität, Theodor-Stern-Kai 7, D 6000, \\ Frankfurt am Main, Federal Republic of Germany
}

(Received I8 May I977; revised 30 August 1977)

\begin{abstract}
Multiple transport systems for L-aspartic acid exist in Streptomyces hydrogenans. The intracellular accumulation of L-aspartate against a concentration gradient was immediately inhibited by proton conductors, such as carbonyl cyanide $p$-trifluoromethoxyphenylhydrazone, 2,4-dinitrophenol or nigericin. Transport activity was gradually lost when inhibitors of protein synthesis were added. L-Aspartate transport had two $\mathrm{pH}$ optima at 6.5 and 4.5. At pH 6.5, two saturable transport components with different $K_{\mathrm{m}}$ and $V_{\max }$ values could be resolved by kinetic studies. A high-affinity system (system I) preferred the L-isomers of the anionic forms of aspartic and glutamic acid. At the same $\mathrm{pH}$, a second, low-affinity system (system II) operated, which was presumably less specific than system I and also able to accept, at high concentrations, neutral amino acids. At $\mathrm{pH} 4.5$, the Lineweaver-Burk plot revealed only a single catalytic component, with $K_{\mathrm{m}}$ and $V_{\max }$ values similar to those of system II. Again, in contrast to system I, this component showed high affinity for neutral amino acids. The data suggest that L-aspartic acid and L-glutamic acid are transported by this system as neutral zwitterionic molecules.
\end{abstract}

\section{INTRODUCTION}

In various micro-organisms, acidic amino acids are actively transported and accumulated inside the cells (for review, see Oxender, 1972). In most species investigated, L-glutamate predominates in the pool of free intracellular amino acids, accounting for $50 \%$ or more of the total, whereas the concentration of L-aspartate is low (Holden, I962; Tempest, Meers \& Brown, I970; Hunter \& Segel, I97I; Oxender, 1972; LangHeinrich \& Ring, 1976). Since L-aspartate and L-glutamate are monovalent anions at physiological $\mathrm{pH}$ values, $\mathrm{L}$-glutamate has been suggested as a regulator of the intracellular ion levels (Gale, 1953; Tempest et al., I970).

In a number of micro-organisms, the uptake of L-aspartate and L-glutamate is mediated by multiple catalytic systems (Halpern \& Even-Soshan, 1967; Reid, Utech \& Holden, 1970; Gross \& Ring, I97I ; Hunter \& Segel, 197I; Kay, 197I ; Wolfinbarger, Jervis \& DeBusk, I97I; Yabu, I97I; Tang \& Howard, 1973). Some of these systems prefer anionic substrates whilst others prefer the neutral form. Accordingly, protons have different effects on the initial uptake rates of L-aspartate and L-glutamate. In some micro-organisms the uptake of L-aspartate and/or L-glutamate is specifically stimulated by monovalent cations, such as $\mathrm{Na}^{+}$and/or $\mathrm{K}^{+}$(Davis et al., 1953; Frank \& Hopkins, 1969; Gross \& Ring, I97I; Gale \& Llewellyn, 1972; Halpern et al., 1973; MacLeod, Thurmann \& Rogers, I973). Conversely, glutamate or aspartate may stimulate the uptake of $\mathrm{K}^{+}$(Davis et al., I953; Eddy \& Indge, I962; Ring, Grimm \& Schwarz, 1976 b). In some, but not all cases, kinetic data suggest a direct coupling between ion and amino-acid fluxes via a common carrier (Halpern et al., I973; Ring et al., 1976). Moreover, in Staphylococcus aureus, Streptococcus faecalis, Saccharo- 
myces cerevisiae (Davis et al., I953; Gale, 1953) and Streptomyces hydrogenans (Gross \& Ring, 1971 ; Ring et al., 1976b) not only the entry but also the accumulation of glutamate is accompanied by an increased uptake of $\mathrm{K}^{+}$. Since the transport of the anionic forms of glutamate and aspartate is electrogenic, such findings are interpreted as a maintenance of electroneutrality.

Because of these properties, the transport systems for the acidic amino acids appear to be suitable models for studying interactions between inorganic ions and amino acids during membrane passage. This communication reports the kinetic properties of L-aspartate transport in Streptomyces hydrogenans. In a subsequent paper we shall describe the influence of extracellular cations on initial rates of L-aspartate uptake.

\section{METHODS}

Preparation of cell suspensions. Streptomyces hydrogenans RT(Ring \& Heinz, 1966; Ring, Ehle \& Foit, 1976a) was maintained on the complete medium agar of Schupp, Hutter \& Hopwood (1975), and grown at $30{ }^{\circ} \mathrm{C}$ in aerated batch cultures on a medium containing peptone, yeast extract, beef extract, glucose and salts, as described by Ring \& Heinz (1966). Cells grown to mid-exponential phase were harvested by centrifuging and washed three times with distilled water. Subsequently, the cells were suspended in $100 \mathrm{~mm}-\mathrm{Tris} / \mathrm{HCl}$ buffer and chilled rapidly to $-2{ }^{\circ} \mathrm{C}$ (cold shock) to remove as much of the pool of free intracellular amino acids as possible (Ring, Gross \& Heinz, 1970; Gross, Ring \& Heinz, 1970). After 20 min, the cells were centrifuged, washed once with cold buffer and suspended in the same buffer to the desired concentration (usually 1 to $2 \mathrm{mg}$ dry cell mass per $\mathrm{ml}$ suspension).

Buffer solutions. For the transport experiments, 25 or $50 \mathrm{~mm}$-citric acid/ $\mathrm{Na}_{2} \mathrm{HPO}_{4}(\mathrm{McIlvaine}$ 's buffer) supplemented with I \% (w/v) glucose and $25 \mathrm{mM}-\mathrm{KCl}$ was usually used (Mcllvaine's $\mathrm{K}^{+}$-buffer). The $\mathrm{pH}$ was adjusted as required.

Uptake experiments. Amino-acid transport was assayed as described by Ring et al. (1976a). Usually, $5 \mathrm{ml}$ cell suspension in a $50 \mathrm{ml}$ Erlenmeyer flask, equipped with a side-arm, was warmed to $30^{\circ} \mathrm{C}$ in a shaking water bath; care was taken to supply sufficient oxygen during the preincubation procedure and the uptake experiment. The uptake was started by adding ${ }^{14} \mathrm{C}$-labelled amino acid (sp. act. about $80 \mu \mathrm{Ci} \mathrm{mmol}{ }^{-1}$ ) from the side-arm. At intervals, $2 \mathrm{ml}$ samples were removed and membrane-filtered (SM I I $308 \mathrm{filter}, 0.15 \mu \mathrm{m}$ pore size; Sartorius). The filtrates were collected and the cells on the filter were washed twice with $2 \mathrm{ml}$ buffer. The filters were placed in scintillation counting vials containing $3 \mathrm{ml}$ absolute methanol, and $30 \mathrm{~min}$ later $12 \mathrm{ml}$ scintillation fluid (Ring et al., 1976a) was added. After vigorous shaking the filter material dissolved completely. The samples were counted by liquid scintillation spectroscopy. Portions of the filtrates $(200 \mu \mathrm{l})$ were treated in the same manner. Corrections for adsorption of radioactivity by the filter material were made for each amino acid.

Calculation of the results. The results are expressed as follows: relative uptake of radioactivity $\left(\mathrm{Ru}^{\prime}\right)=$ $\mathrm{u}_{\mathrm{c}}^{\prime} / \mathrm{a}_{\mathrm{f}}^{\prime}\left(\mathrm{ml} \mathrm{g} \mathrm{g}^{-1}\right)$, where $\mathrm{u}_{\mathrm{c}}^{\prime}=$ c.p.m. per $\mathrm{g}$ dry cell mass and $\mathrm{a}_{\mathrm{i}}^{\prime}=$ c.p.m. per ml extracellular fluid; absolute uptake rate $(v)=\mathbf{R u}^{\prime} \times \mathbf{a}_{\mathrm{f}}\left(\mu \mathrm{mol} \mathrm{g^{-1 }}\right.$ per unit time), where $\mathrm{a}_{\mathrm{f}}=\mu \mathrm{mol}$ amino acid per ml suspension.

Preparation of cell-free extracts and separation of labelled pool components. At intervals after adding ${ }^{14} \mathrm{C}$-labelled L-aspartate, cells were collected by filtering and washed once with buffer. The filters were immediately transferred to boiling water or ice-cold $5 \%(\mathrm{w} / \mathrm{v}) \mathrm{HClO}_{4}$. After $5 \mathrm{~min}$, the cell debris was separated from the pool components by membrane filtration, and the filtrate was freeze-dried overnight. This material was then dissolved in a small volume of water and the amino acids were separated by thin-layer chromatography on cellulose using butan-I-ol/acetic acid/water (4:I:I, by vol.) and propan-2-ol/formic acid/water (20:I:I, by vol.). Krebs cycle intermediates were separated by thin-layer chromatography on cellulose using diethyl ether/formic acid/water (7:2:1, by vol.). Radioactive compounds were located using a radio thin-layer chromatograph scanner (Berthold-Friesecke, Wildbad, West Germany) or by autoradiography with medical X-ray film (Kodak Regulix BB54).

Special chemicals. Radioactive amino acids were from Amersham-Buchler, Braunschweig, West Germany. Unlabelled amino acids were purchased as chromatographically pure products from Fluka, Buchs, Switzerland. Antimycin A, oligomycin, carbonyl cyanide $p$-trifluoromethoxyphenylhydrazone (FCCP) and chloramphenicol were obtained from Boehringer. Nigericin was kindly supplied by Dr E. Heinz. All other chemicals were analytical grade reagents. 


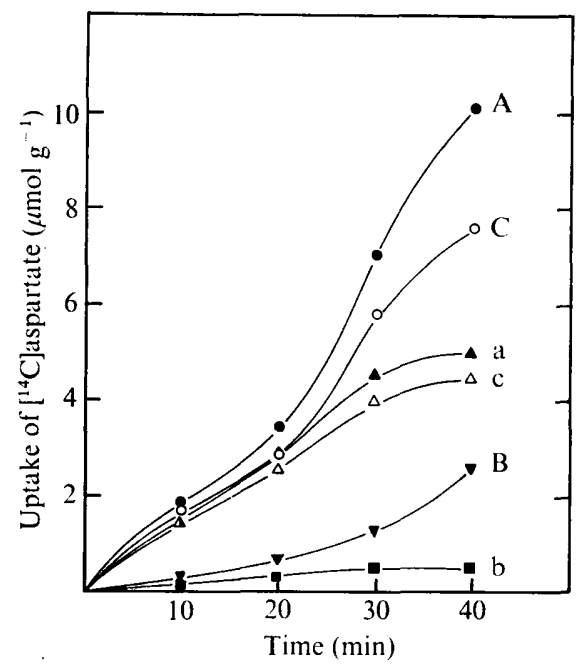

Fig. I. Aspartate transport into $S$. hydrogenans RT and incorporation into protein. Cells were incubated in $25 \mathrm{mM}-\mathrm{Mcll}$ vaine's $\mathrm{K}^{+}$-buffer, $\mathrm{pH} 6 \cdot 0$, at $30^{\circ} \mathrm{C}$, with $0.1 \mathrm{mM}-\mathrm{L}-\left[\mathrm{U}-{ }^{14} \mathrm{C}\right]$ aspartate, in the absence (curves A, B, C) or presence (curves $\mathrm{a}, \mathrm{b}, \mathrm{c}$ ) of $50 \mu \mathrm{g}$ chloramphenicol ml ${ }^{-1}$. Before starting the experiment, the cells were preincubated for $5 \mathrm{~min}$ with/without the inhibitor. A, a, Total uptake of label into the cells; B, b, incorporation of label into the TCA-insoluble fraction; C, c, uptake of label into the TCA-soluble pool (data calculated from curves $A$ and $B$, and $a$ and $b$, respectively).

\section{RESULTS AND DISCUSSION}

Time course of uptake of $\mathrm{L}-\left[{ }^{4} \mathrm{C}\right]$ aspartic acid

After uptake of $\mathrm{L}_{\mathrm{L}}\left[{ }^{14} \mathrm{C}\right] \mathrm{aspartic}$ acid into $S$. hydrogenans (Fig. I, curve A), a substantial portion of the label was incorporated in the trichloroacetic acid (TCA)-insoluble fraction (Fig. I, curve B). Uptake of label into the TCA-soluble pool (Fig. I, curve C) was calculated from the difference between curves A and B. Since there is metabolism of the transported $\left[{ }^{14} \mathrm{C}\right]$ aspartate during incubation, the actual concentration of $\left[{ }^{14} \mathrm{C}\right]$ aspartate in this pool is lower than reflected by curve $\mathrm{C}$, as will be discussed later. The course of uptake was complex resulting in a biphasic curve. Even after $50 \mathrm{~min}$, no steady-state distribution of free radioactivity was reached.

Similar complex uptake curves have been observed previously for the uptake of glutamate under similar experimental conditions by $S$. hydrogenans HR, the parent strain of RT used in this study (Gross \& Ring, 197I). The stimulation of the uptake of glutamate after approximately $20 \mathrm{~min}$ was interpreted as indicating that the uptake of glutamate was under positive control of an intracellular effector formed from L-glutamate. Accordingly, this phenomenon was termed feedback-stimulation or 'trans-stimulation' (Gross et al., 1970). A number of other amino acids have been identified as precursors of stimulators. L-Aspartate is one of the most effective. Thus, the stimulation of L-aspartate uptake in the second phase of the experiment (Fig. I) may be understood in terms of the trans-stimulation phenomenon.

\section{Effect of chloramphenicol on the uptake of $\mathrm{L}-\left[{ }^{14} \mathrm{C}\right]$ aspartate}

To minimize incorporation of label into protein during uptake experiments, inhibitors of either transcription or translation are frequently employed. Within the first minutes of uptake of $\left[{ }^{14} \mathrm{C}\right]$ aspartate into $S$. hydrogenans, the net uptake of label was slightly decreased in the presence of chloramphenicol (Fig. I, curve a); the decrease corresponded to the amount of label incorporated into protein in the inhibitor-free cells (curve B). However, as incubation continued, uptake progressively deviated from that expectation. Again, this 
Table I. Inhibition of aspartate influx by metabolic inhibitors

L-Aspartate influx ( $3 \mathrm{~min}$ ) was measured after preincubating cells for $5 \mathrm{~min}$ in the presence of additives, as indicated. The aspartate concentration was $27 \mu \mathrm{M}$; the incubation fluid was $50 \mathrm{~mm}-$ McIlvaine's $\mathrm{K}^{+}$-buffer, $\mathrm{pH} 6 \cdot 5$. Values are means of four determinations.

$\begin{array}{lcc}\text { Inhibitor } & \text { Concn (mM) } & \begin{array}{c}\text { Inhibition } \\ \text { of transport } \\ (\%)\end{array} \\ \text { None } & - & 0 \\ \text { 2,4-Dinitrophenol } & 0.4 & 96 \\ \text { FCCP } & 0.8 & 97 \\ \text { Nigericin } & 0.0065 & 95 \\ \text { NaN }_{3} & 0.001 & 99 \\ & 4.0 & 79 \\ \text { KCN } & 8.0 & 81 \\ & 0.4 & 35 \\ \text { Antimycin A } & 0.8 & 67 \\ & 0.1 & 27 \\ \text { Oligomycin } & 0.2 & 41 \\ & 0.001 & 75 \\ & 0.01 & 73\end{array}$

finding is similar to that observed by Gross \& Ring (1969) on the effect of chloramphenicol and actinomycin on the uptake of various amino acids into cells of the same species, and agrees with reports involving other species (Holden \& Utech, 1967; Wiley \& Matchett, 1968). Inhibition of transport by such compounds is explained by assuming that ratelimiting transport proteins, probably the carrier molecules, have a high rate of turnover. Thus, by inhibiting de novo protein synthesis, resynthesis is prevented and a progressive loss of transport capacity must be expected. Consequently, in the subsequent experiments these inhibitors were not employed unless otherwise stated.

\section{Metabolism of $\mathrm{L}$-aspartate}

To study the metabolic fate of L-aspartate, cells were incubated for $5 \mathrm{~min}$ with [U- $\left.{ }^{14} \mathrm{C}\right]-$ aspartate under standard conditions in McIlvaine's buffer at $\mathrm{pH} 6.5$ in the presence or absence of chloramphenicol (100 $\mu \mathrm{g} \mathrm{ml}^{-1}$ ). On analysis of soluble material extracted from cells (see Methods), about $35 \%$ of the intracellular free radioactivity was recovered as aspartic acid, $55 \%$ was identified as glutamate, $3 \%$ as alanine and about $3 \%$ as serine. Traces of Krebs cycle intermediates, mainly citrate, oxoglutarate, succinate and fumarate, were also detected. Chloramphenicol did not affect the distribution pattern of the intracellular free radioactivity.

In these experiments the average distribution ratio of label between cells and medium $\left(\mathrm{Ru}^{\prime}\right)$ was $180 \mathrm{ml} \mathrm{g}^{-1}$. If $80 \%$ of the cell wet weight is water, the intracellular free aspartate is accumulated I6-fold over that in the external medium. This implies that the catalytic system for aspartate transport can mediate transport against a concentration gradient. Most of the aspartate, however, is metabolized to glutamate immediately on entry into the cells. Similar observations have been reported for a variant of E. coli KI2 (Kay, 197I).

\section{Effect of metabolic inhibitors on initial transport rates}

The effects of various types of metabolic inhibitors (Table I) indicated that aspartate transport was dependent on the availability of a suitable energy source. Generally, agents which selectively block electron transfer in the respiratory chain, e.g. antimycin A, azide and cyanide, did not completely abolish the aspartate influx, even at high doses. Impairment of the oxidative phosphorylation by adding oligomycin also gave incomplete inhibition. However, rapid and almost complete inhibition of aspartate uptake was produced by 


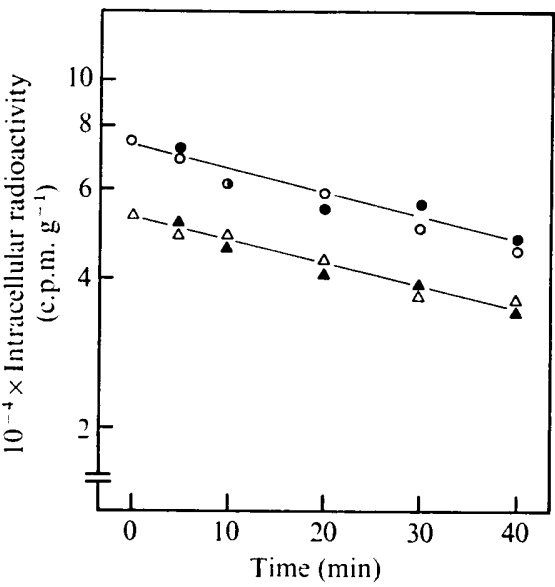

Fig. 2

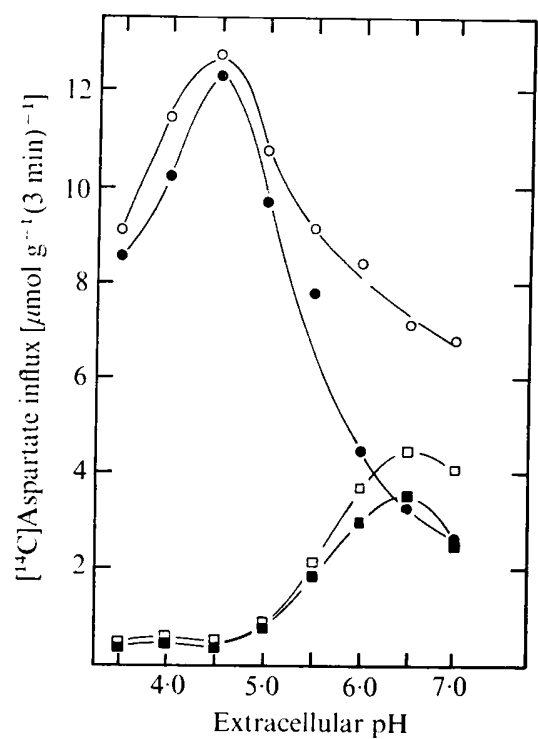

Fig. 3

Fig. 2 Efflux of aspartate. Cells were preincubated in $50 \mathrm{mm-McIlvaine's} \mathrm{K}^{+-}$-buffer, pH $6 \cdot 0$, at $30^{\circ} \mathrm{C}$ with I mM-L-[U-14 C]aspartate in the absence $(O, O)$ or presence $(\Delta, \Delta)$ of $50 \mu \mathrm{g}$ chloramphenicol ml-1. After $30 \mathrm{~min}$, the cells were separated from the medium by membrane filtration and resuspended in the same buffer, without aspartate or chloramphenicol. After 5 min incubation at $30{ }^{\circ} \mathrm{C}(=$ time 0$)$, the efflux experiment was started by addition of either unlabelled $\mathrm{I}$ mM-L-aspartate $(O, \Delta)$ or an equal volume of buffer $(O, \Delta)$.

Fig. 3. Dependence of aspartate influx on the extracellular pH. Freshly prepared cells were suspended in distilled water, and samples were mixed with equal volumes of either $200 \mu_{\mathrm{M}}(\square, \boldsymbol{\square})$ or $\mathrm{I} 00 \mu_{\mathrm{M}}(\square, \bigcirc) \mathrm{McIlvaine's} \mathrm{K}^{+}$-buffer solutions adjusted to the $\mathrm{pH}$ values indicated. Immediately afterwards the $3 \mathrm{~min}$ influx of $\mathrm{L}-\left[\mathrm{U}-{ }^{14} \mathrm{C}\right]$ aspartate $(\square, \square, 8 \cdot 3 \mu \mathrm{M} ; O, O, 525 \mu \mathrm{M})$ at $30{ }^{\circ} \mathrm{C}$ was determined.

proton-conducting agents, such as FCCP, DNP and nigericin. The inhibition by these compounds was not correlated with the decay of ATP (K. Ring, unpublished observations) suggesting that a proton gradient may be involved in the uptake and accumulation of aspartate. This would be consistent with recent reports on energy coupling of amino-acid transport in other bacteria (Harold \& Altendorf, I974; Hamilton, 1975).

\section{Efflux of radioactivity from preloaded cells}

Cells preloaded for $30 \mathrm{~min}$ with $\left[{ }^{14} \mathrm{C}\right]$ aspartate lost radioactivity at a low constant rate when transferred to aspartate-free buffer (Fig. 2). The loss of radioactivity was not accompanied by a corresponding increase in extracellular radioactivity. Although more than $60 \%$ of the intracellular label was present in free aspartate when the efflux was started, almost no $\left[{ }^{14} \mathrm{C}\right]$ aspartate could be detected chromatographically in the incubation fluid even after 60 min. Presumably, most of the label was lost as ${ }^{14} \mathrm{CO}_{2}$. These findings confirm earlier observations that the cell membrane of this organism is impermeable to highly polar amino acids.

Addition of unlabelled aspartate to the incubation buffer did not accelerate loss of radioactive material, so aspartate is apparently unable to leave the cells via an exchange diffusion mechanism. This was supported by the observation that cells preloaded with aspartate in the absence and presence of chloramphenicol lost ${ }^{14} \mathrm{C}$-labelled material at similar rates (Fig. 2). Since, as shown above, the system for aspartate uptake is sensitive to inhibitors of de novo protein synthesis, these results also argue against an involvement of the aspartate uptake system in aspartate efflux. 


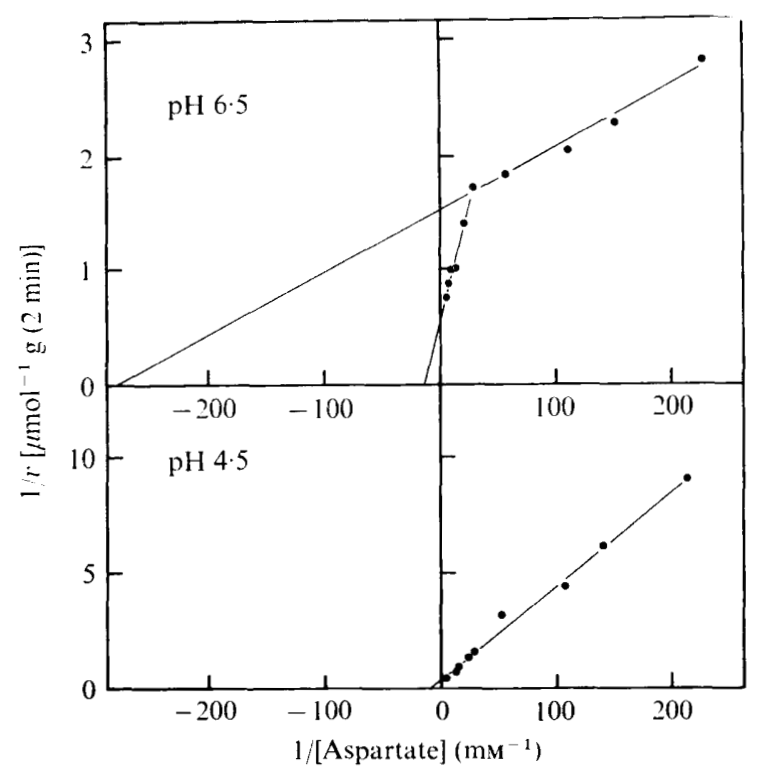

Fig. 4. Kinetics of $\mathrm{L}$-aspartate influx at $\mathrm{pH} 6.5$ and 4.5 . The incubation fluid was 50 mM-Mcllvaine's $\mathrm{K}^{+}$-buffer. The $2 \mathrm{~min}$ uptake of $\mathrm{L}_{-}\left[\mathrm{U}_{-}{ }^{14} \mathrm{C}\right]$ aspartate was measured at $30^{\circ} \mathrm{C}$. The results are plotted as reciprocal uptake rates versus reciprocal external aspartate concentrations in the usual manner.

\section{Effect of extracellular $\mathrm{pH}$ on initial uptake rates of $\left[{ }^{14} \mathrm{C}\right]$ aspartate}

Two transport optima, depending on the incubation conditions, were observed (Fig. 3). At low external aspartate concentration, the uptake rate was maximum at $\mathrm{pH} 6.5$ (a second, extremely small but significant peak was usually detected at $\mathrm{pH} 4{ }^{\circ}$ ). At high external aspartate concentration, the transport maximum was at $\mathrm{pH} 4 \cdot 5$. Thus two different catalytic sites are involved in aspartate uptake into $S$. hydrogenans $\mathbf{R T}$.

Between $\mathrm{pH} 7.0$ and 5.5 , aspartate exists almost exclusively as monovalent anions. Thus, the peak observed at $\mathrm{pH} 6.5$ may reflect the activity of a system that prefers the anionic form of aspartate. The neutral zwitterion of aspartate, on the other hand, might be the substrate of the second catalytic component operating at a low external $\mathrm{pH}$.

Support for the proposal that two different catalytic sites mediate aspartate uptake was provided by the marked inhibition of aspartate transport in the range of the first transport maximum when the ionic strength of the incubation medium was increased. At $\mathrm{pH} 6.5$ the buffer solution contains large amounts of phosphate ions and, in particular, di- and trivalent citrate anions. The inhibition of aspartate uptake might be understood in terms of a competition between the amino acid and the divalent buffer components at the recognition site for the aspartate anion.

\section{Kinetics of aspartate transport}

Initial rates of $\left[{ }^{14} \mathrm{C}\right]$ aspartate uptake were determined at various concentrations of aspartate in 50 mM-McIlvaine's buffer at $\mathrm{pH} 6.5$ and 4.5 . The results, when plotted as reciprocal uptake rates versus reciprocal external aspartate concentrations (Fig. 4), indicated that at $\mathrm{pH} 6.5$ two saturable catalytic components with widely different affinities for asparatate were operating. The following kinetic parameters were derived: $K_{\mathrm{m}_{1}}=3.92 \mu \mathrm{M}$, $V_{\max _{1}}^{\mathrm{in}}=0.67 \mu \mathrm{mol} \mathrm{g}^{-1}(2 \mathrm{~min})^{-1} ; K_{\mathrm{m}_{2}}=7 \mathrm{r} \cdot 0 \mu \mathrm{M}, \quad V_{\max _{2}}^{\mathrm{in}}=3.7 \mu \mathrm{mol} \mathrm{g}^{-1}(2 \mathrm{~min})^{-1}$. At $\mathrm{pH} 4 \cdot 5$, only a single, relatively low-affinity catalytic component with a $K_{\mathrm{m}}$ value of i $10 \mu \mathrm{M}$ and a $V_{\max }$ of $2.86 \mu \mathrm{mol} \mathrm{g}^{-1}(2 \mathrm{~min})^{-1}$ was found (Fig. 4). A second catalytic component operating at higher affinity was not detected.

At least two functional catalytic sites therefore mediate the transport of aspartate into 


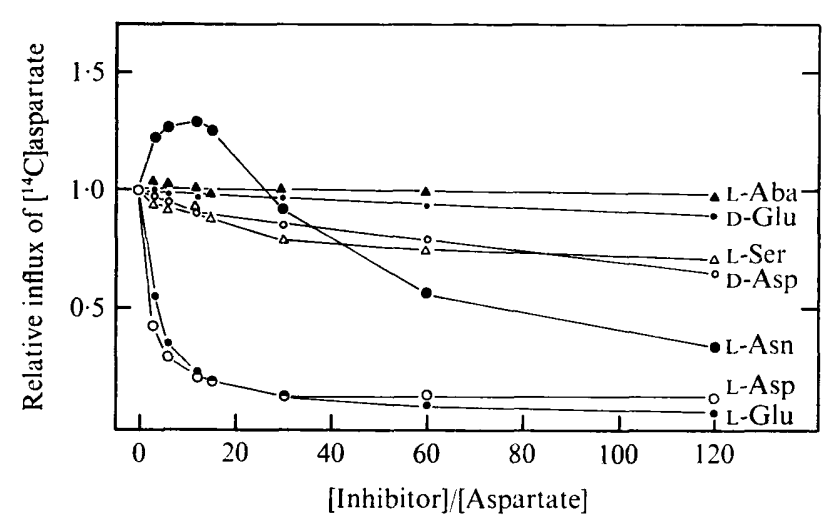

Fig. 5. Specificity of L-aspartate transport at pH 6.5. Cells were incubated in $50 \mathrm{~mm}$-Mcllvaine's $\mathrm{K}^{+-}$ buffer at $30^{\circ} \mathrm{C}$. L-[U- $\left.{ }^{14} \mathrm{C}\right]$ Aspartate influx ( $3 \mathrm{~min}$; aspartate concentration $12 \mu \mathrm{M}$ ) was measured in the presence of various concentrations of unlabelled amino acids. Relative transport rate is plotted against the ratio of inhibitor to substrate concentration.

S. hydrogenans $\mathrm{RT}$ at $\mathrm{pH} 6.5$ : a high-affinity system with low capacity (system I) and a lowaffinity system with high capacity (system II). These results agree with observations on L-glutamate uptake by S. hydrogenans HR (Gross \& Ring, 197I). Moreover, in a variety of other micro-organisms multiple transport systems for acidic amino acids have been detected (Halpern \& Even-Soshan, I967; Reid et al., 1970; Gross \& Ring, 1971; Hunter \& Segel, 1971; Kay, 197I; Wolfinbarger et al., 1971; Yabu, 1971; Tang \& Howard, 1973).

The $K_{\mathrm{m}}$ value of the catalytic component which operates at low $\mathrm{pH}$ is close to the $K_{\mathrm{m}}$ value of system II at pH 6.5 and the two systems may be identical. Competition experiments, presented below, favour such an assumption. However this type of graphical analysis will not separate catalytic components unless their $K_{\mathrm{m}}$ values are sufficiently different from each other (Gross et al., I972). Since the affinity of system I could be lowered as the extracellular $\mathrm{pH}$ is decreased, perhaps due to interactions between protons and the catalytic site itself, system I might still operate at low $\mathrm{pH}$.

\section{Substrate specificity of L-aspartate transport}

Initial rates of $\left[{ }^{14} \mathrm{C}\right]$ aspartate uptake were determined in the presence of various amino acids at $\left.\mathrm{pH} 6 \cdot 5 \cdot{ }^{14} \mathrm{C}\right]$ Aspartate was initially present in the incubation mixture at $12 \mu \mathrm{M}$, i.e. approximately three times the $K_{\mathrm{m}}$ of system I and far below the $K_{\mathrm{m}}$ of system II. The concentrations of the amino acids tested were varied over a wide range up to 250 times the aspartate concentration. Uptake of $\left[{ }^{14} \mathrm{C}\right]$ aspartate was inhibited by L-aspartate and by L-glutamate to almost the same extent at all concentrations tested (Fig. 5). The D-isomers of these amino acids, on the other hand, showed different effects. Even at low concentrations, D-aspartate significantly inhibited L-aspartate transport, whereas D-glutamate was ineffective, or nearly so, even at a high excess. Among the neutral amino acids, L-aminobutyric acid was a poor inhibitor. However, L-serine and L-asparagine showed considerable affinities for the transport sites for L-aspartate.

Although the rate of aspartate uptake was enhanced in the presence of small amounts of L-asparagine and analogous observations have been made with other micro-organisms (Kotyk, Ponec \& Rihová, 197I), this phenomenon was not investigated further. The inhibitory properties of L-asparagine might be due to the high degree of polarity of the sidechain that enables this amino acid to interact with the presumably positively charged recognition site for the $\omega$-carboxylic group of the aspartate anion. This argument could be extended to the observed inhibition of aspartate uptake by methionine (Table 2). Other neutral 
Table 2. Inhibition of aspartate influx by various amino acids

L-Aspartate uptake ( $3 \mathrm{~min}$ ) was measured in the presence of a 1000-fold excess of various amino acids. The incubation fluid was 25 mM-McIlvaine's $\mathrm{K}^{+}$-buffer, $\mathrm{pH} \mathrm{6.5}$; the aspartate concentration was $30 \mu \mathrm{M}$. Values are means of three determinations.

\begin{tabular}{lc}
\multicolumn{1}{c}{ Amino acid added } & $\begin{array}{c}\text { Transport } \\
\text { activity }(\%)\end{array}$ \\
None & I00 \\
Glycine & 86 \\
L-Alanine & 81 \\
L-Valine & 86 \\
L-Serine & 62 \\
L-Methionine & 56 \\
2-Aminoisobutyric acid & 85 \\
DL-Cysteic acid & 3
\end{tabular}

amino acids which lack a polar end group were also able to inhibit L-aspartate uptake, although to a limited degree and at very high excess (Table 2).

Further information on the specificities of the transport systems was obtained by comparing uptake at $\mathrm{pH} 4.0$ and 6.5 . The specificity of aspartate transport differed significantly at the two $\mathrm{pH}$ values (Fig. 6). These studies were carried out simultaneously at $\mathrm{pH} 4^{\circ} \mathrm{O}$ and 6.5 using cells from the same batch. In agreement with previous kinetic data (Fig. 4), the affinity of aspartate for its transport catalyst was significantly lowered when the $\mathrm{pH}$ was shifted from 6.5 to 4.0 . L-Glutamate, which at $\mathrm{pH} 6.5$ had almost the same affinity for the aspartate site as aspartate itself, did not completely inhibit aspartate uptake at $\mathrm{pH} 4.0$, even if added in large excess (Fig. 6). L-Alanine, a poor inhibitor at $\mathrm{pH} 6.5$, had a higher affinity for the transport catalyst at $\mathrm{pH} 4.0$ than did aspartate itself. Nevertheless, L-alanine did not completely inhibit aspartate transport at $\mathrm{pH} 4 \cdot 0$ (Fig. 6).

When the uptake of labelled L-glutamate was measured in the presence of unlabelled L-glutamate, L-aspartate or L-alanine, a similar pattern of specificity was obtained (Fig. 7) as in the uptake of labelled aspartate.

Neither L-aspartate nor L-glutamate inhibited the uptake of $\left[{ }^{14} \mathrm{C}\right]$ alanine at $\mathrm{pH} 6.5$, but at $\mathrm{pH} 4.0$ they did so significantly (Fig. 8). Thus, at high $\mathrm{pH}$ values, L-aspartate and L-glutamate probably share a common transport system which has only a low affinity for alanine. Conversely, L-aspartate and L-glutamate do not interact substantially with the transport catalyst for alanine. At low $\mathrm{pH}$ values, however, $\mathrm{L}$-aspartate and L-glutamate are transported by a catalytic system which has high affinity for L-alanine thus suggesting that at this $\mathrm{pH}$ L-aspartate and L-glutamate are transported mainly as zwitterions. Nevertheless, since L-alanine failed to inhibit L-aspartate and L-glutamate uptake completely even when added in high excess, there may be an additional, specific system for L-aspartate and L-glutamate operative at $\mathrm{pH} 4.0$ which might prefer the anionic form.

Uptake of $\left[{ }^{14} \mathrm{C}\right]$ aspartate at various $\mathrm{pH}$ values in the presence of unlabelled L-aspartate, L-glutamate and L-alanine is summarized in Fig. 9.

\section{Acceleration of efflux of 2-amino[ $\left[-{ }^{14} C\right]$ isobutyric acid by extracellular $\mathrm{L}$-aspartate and $\mathrm{L}-$ glutamate}

Carrier-mediated efflux of an intracellular amino acid can often be accelerated by adding external amino acids that share a common transport system with the amino acid inside the cells. This phenomenon provides an additional means of studying the specificity of a given transport system.

Since aspartate does not leave $S$. hydrogenans by exchange diffusion, the specificity of efflux was studied using 2-aminoisobutyric acid (AIB), which is transported in these cells by the uptake systems for short-chain neutral amino acids (Ring \& Heinz, 1966; Rudorf, 


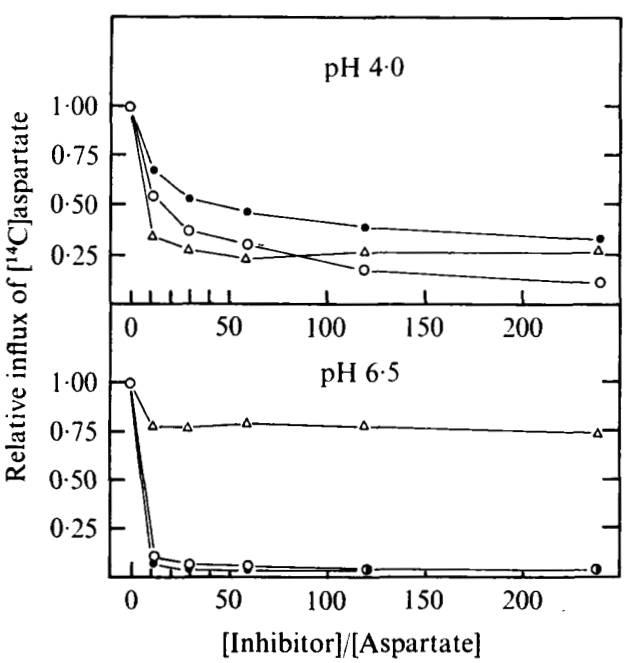

Fig. 6

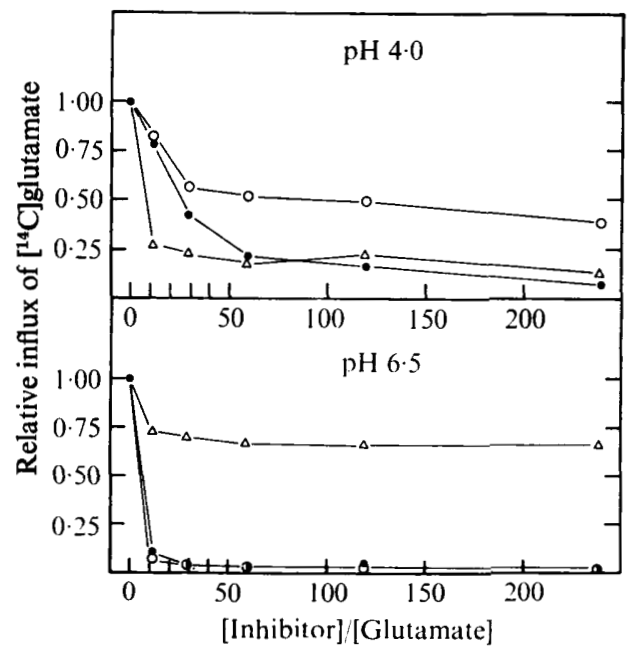

Fig. 7

Fig. 6. Specificity of L-aspartate transport at $\mathrm{pH} 4.0$ and 6.5. Experimental conditions as described in Fig. 5. Inhibitors: $O$, L-aspartate; $\bullet, L$-glutamate; $\triangle$, L-alanine.

Fig. 7. Specificity of $\mathrm{L}$-glutamate transport at $\mathrm{pH} 4 \cdot 0$ and 6.5. Experimental conditions as described in Fig. 5. The $\left[{ }^{14} \mathrm{C}\right]$ glutamate concentration was $12 \mu \mathrm{M}$. Inhibitors: $\mathrm{O}, \mathrm{L}$-aspartate; $\bullet$, L-glutamate; $\Delta$, L-alanine.

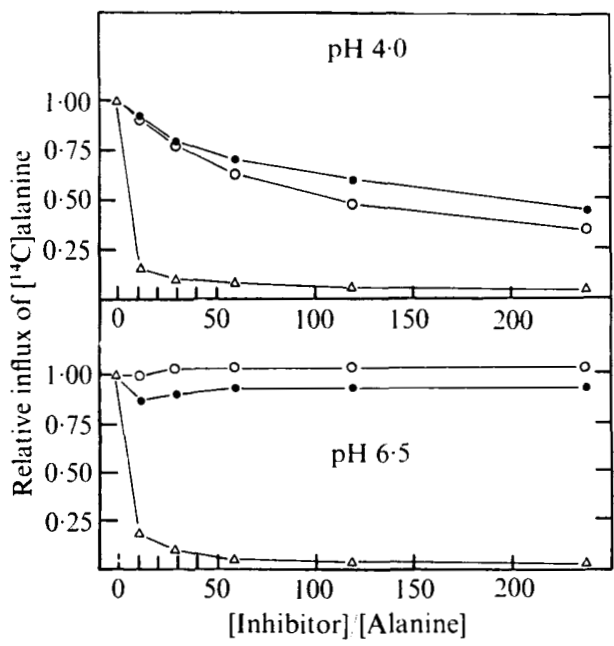

Fig. 8

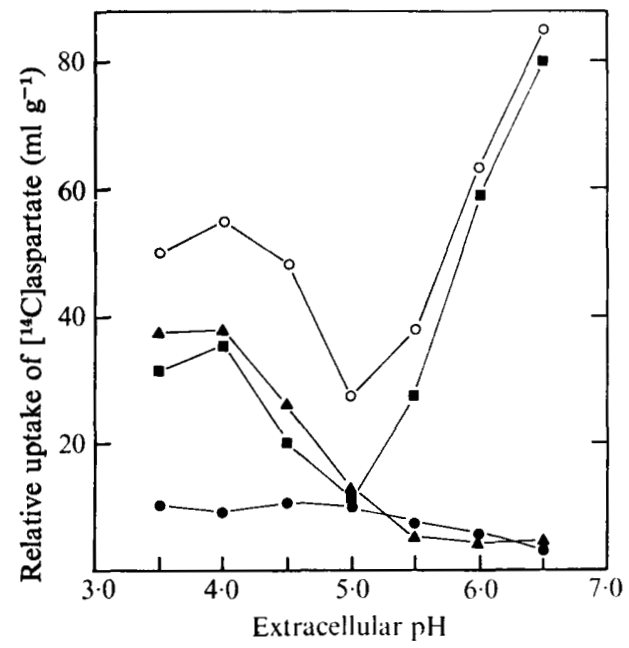

Fig. 9

Fig. 8. Specificity of L-alanine transport at $\mathrm{pH} 4 \cdot 0$ and 6.5. Experimental conditions as described in Fig. 5. The $\left[{ }^{14} \mathrm{C}\right]$ alanine concentration was $12 \mu \mathrm{M}$. Inhibitors: $\bigcirc$, L-aspartate; , L-glutamate; $\triangle$, L-alanine.

Fig. 9. Effect of external $\mathrm{pH}$ on the influx of $\mathrm{L}$-aspartate in the presence of unlabelled L-aspartate, L-glutamate and $L$-alanine. Cells were suspended in distilled water and samples were mixed with equal volumes of $100 \mathrm{~mm}$ buffer solutions adjusted to the $\mathrm{pH}$ values indicated. Immediately afterwards the $3 \mathrm{~min}$ influx of $\mathrm{L}-\left[\mathrm{U}-{ }^{14} \mathrm{C}\right]$ aspartate $(12 \mu \mathrm{M})$ was measured in the presence of $\mathrm{I} \cdot 5 \mathrm{~mm}$ unlabelled $\mathbf{L}$-aspartate (O), L-glutamate ( $\Delta)$, L-alanine $(\mathbf{D})$, or an equal volume of buffer $(O)$. 


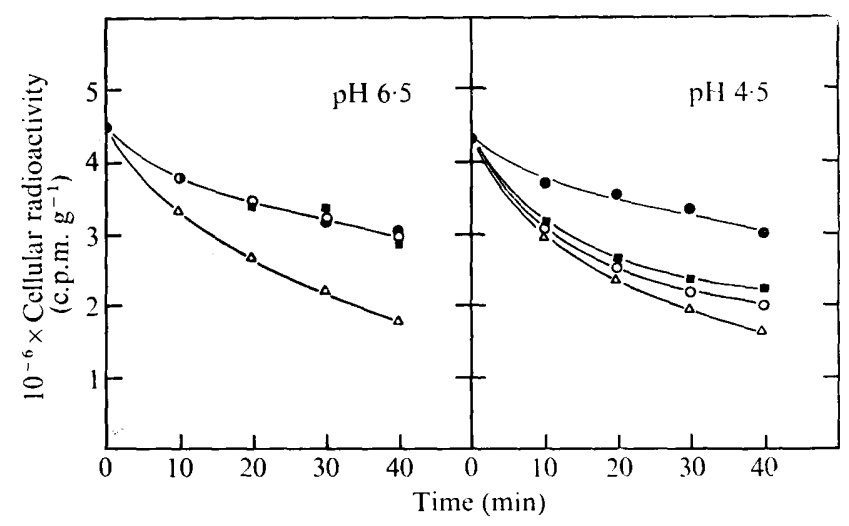

Fig. 10. Efflux of 2-aminoisobutyric acid at $\mathrm{pH} 6.5$ and 4.5 . Cells were preincubated in $50 \mathrm{~mm}-$ Mcllvaine's $\mathrm{K}^{+}$-buffer at $30^{\circ} \mathrm{C}$ with $\mathrm{I} \mathrm{mM-2}$-amino[ $\mathrm{I}^{-14} \mathrm{C}$ ] isobutyric acid. After $60 \mathrm{~min}$, the cells were separated from the medium by membrane filtration and resuspended in McIlvaine's $\mathrm{K}^{+}$-buffer adjusted to $\mathrm{pH} 6 \cdot 5$ or 4.5 . The efflux of label was measured after addition of $\mathrm{I} \cdot 2 \mathrm{~mm}$ unlabelled L-alanine $(\triangle)$, L-glutamate $(\mathbf{})$, L-aspartate $(O)$, or an equal volume of buffer $(\mathcal{O})$.

197I). Unlike glycine and alanine, it is not metabolized. Cells were preloaded with labelled AIB, and the efflux of radioactivity into AIB-free incubation medium was followed after adding either L-alanine, L-aspartate or L-glutamate. At pH 6.5 only L-alanine substantially stimulated AIB efflux. At $\mathrm{pH} 4.5$, however, aspartate and glutamate also accelerated AIB efflux, but to a somewhat lesser extent than alanine (Fig. 10). This finding provides further support for the assumption that at low $\mathrm{pH}$ values the acidic amino acids are mainly transported as zwitterions, sharing a transport system with neutral amino acids.

\section{General conclusions}

The uptake of L-aspartate into $S$. hydrogenans RT is mediated by multiple catalytic systems exhibiting different substrate specificities. At $\mathrm{pH} 6 \cdot 5$, L-aspartate and L-glutamate are transported by a high-affinity system (system I) which has no substantial affinity for neutral amino acids: the catalytic site probably interacts with the anionic form of the acidic amino acids. At high substrate concentrations a second catalytic component (system II) for aspartate and glutamate transport becomes operative, which has a low affinity for the acidic amino acids. System II has an appreciable affinity for neutral amino acids such as alanine. Whether it is identical with one of the catalytic components for neutral aminoacid transport, or whether it is equivalent to the 'general permease' detected in various other micro-organisms (Oxender, 1972) is not yet clear. At lower $\mathrm{pH}$, the activity of the highaffinity system is drastically decreased and it may not operate at all. Instead a catalytic component predominates which interacts both with the acidic amino acids and with neutral amino acids. This site is possibly identical with system II and its preferred substrates will be the neutral zwitterions of aspartate and glutamate. Despite the catalytic site having a significantly higher affinity for neutral amino acids than for acidic amino acids, neutral amino acids are unable to inhibit completely the uptake of L-aspartate and L-glutamate which suggests that system $\mathrm{I}$ has a residual activity at low $\mathrm{pH}$.

This paper is dedicated to Prof. Dr E. Heinz on the occasion of his 65th birthday.

We are indebted to the Deutsche Forschungsgemeinschaft for financial support (grants Ri I50). 


\section{REFERENCES}

Davis, R., Folkes, J. P., Gale, E. F. \& Bigger, L. C. (I953). The assimilation of amino-acids by micro-organisms. Biochemical Journal 54, 430437.

EDDY, A. A. \& INDGe, K. J. (1962). Amino acid transport and acid-base balance in yeast. Biochemical Journal 85, 35P-36P.

Frank, L. \& Hopkins, I. (1969). Sodium-stimulated transport of L-glutamate in Escherichia coli. Journal of Bacteriology 100, 329-336.

GALE, E. F. (1953). Assimilation of amino acids by gram-positive bacteria and some actions of antibiotics thereon. Advances in Protein Chemistry 8, 285-391.

Gale, E. F. \& Llewellyn, J. M. (1972). The role of hydrogen and potassium ions in the transport of acidic amino acids in Staphylococcus aureus. Biochimica et biophysica acta 226, I 82-205.

Gross, W. \& RING, K. (1969). Effect of chloramphenicol on active amino acid transport. FEBS Letters 4, 319-322.

Gross, W. \& RING, K. (I971). Active transport of glutamate in Streptomyces hydrogenans. I. Studies on uptake and pool size and their interrelationship. Biochimica et biophysica acta 233, 652-665.

Gross, W., RING, K. \& HeInz, E. (I970). Positive feedback regulation of amino acid transport in Streptomyces hydrogenans. Archives of Biochemistry and Biophysics I37, 253-26I.

Gross, W., Geck, P., Burckhardt, K.-L. \& RinG, K. (1972). Kinetic analysis of two component systems in transmembrane transport (multiple forms of transport systems). Biophysik 8, 271-279.

Halpern, Y. S. \& EVen-Soshan, A. (1967). Properties of the glutamate transport system in Escherichia coli. Journal of Bacteriology 93, 1009-I016.

HalPern, Y. S., Barash, H., Dover, S. \& Druck, K. (1973). Sodium and potassium requirements for active transport of glutamate by $E$. coli $\mathrm{K}-\mathrm{I} 2$. Journal of Bacteriology II4, 53-58.

Hamilton, W. A. (1975). Energy coupling in microbial transport. Advances in Microbial Physiology 12, 1-53.

Harold, F. M. \& AltendorF, K. H. (1974). Cation transport in bacteria: $\mathrm{K}^{+}, \mathrm{Na}^{+}$, and $\mathrm{H}^{+}$. In Current Topics in Membranes and Transport, vol. 5, pp. I-50. Edited by F. Bronner and A. Kleinzeller. New York: Academic Press.

Holden, J. T. (1962). Amino Acid Pools. Amsterdam: Elsevier.

HoldEN, J. T. \& UTECH, N. M. (1967). Actinomycin D inhibition of amino acid transport in Streptococcus faecalis. Biochimica et biophysica acta $\mathbf{1 3 5}, 35 \mathrm{I}-354$.

Hunter, D. R. \& Segel, I. (I97I). Acidic and basic amino acid transport systems of Penicillium chrysogenum. Archives of Biochemistry and Biophysics 144, 168-183.

KAY, W. W. (1971). Two aspartate transport systems in Escherichia coli. Journal of Biological Chemistry 246, 7373-7382.
Kotyk, A., Ponec, M. \& RihovÁ, L. (197I). Uptake of amino acids by actidione-treated yeast cells. I. Specificity of carriers. Folia Microbiologica I6, 432-444.

LaNGHeINRICh, W. \& Ring, K. (1976). Regulation of amino acid transport in growing cells of Streptomyces hydrogenans. I. Modulation of transport capacity and amino acid pool composition during the growth cycle. Archives of Microbiology ro9, 227-235.

Macleod, R., Thurmann, P. \& Rogers, H. T. (1973). Comparative transport activities of intact cells, membrane vesicles and mesosomes of Bacillus licheniformis. Journal of Bacteriology $\mathbf{1 1 3}$, 329-340.

OXENDER, D. (1972). Amino acid transport in microorganisms. In Metabolic Pathways, vol. 6, pp. I33185. Edited by L. E. HokIN. New York: Academic Press.

ReID, K. G., UteCh, N. M. \& Holden, J. T. (I970). Multiple transport components for dicarboxylic amino acids in Streptococcus faecalis. Journal of Biological Chemistry 245, 5261-5272.

RiNG, K. \& HeINZ, E. (I966). Active amino acid transport in Streptomyces hydrogenans. Biochemische Zeitschrift 344, 446-46I.

RING, K., Gross, W. \& HeInZ, E. (1970). Negative feedback regulation of amino acid transport in Streptomyces hydrogenans. Archives of Biochemistry and Biophysics 137, 243-252.

RING, K., EHLE, H. \& FoIT, B. (I976a). Effect of alkali ions on the active transport of neutral amino acids into Streptomyces hydrogenans. Biochimica et biophysica acta 433, 61 5-629.

RING, K., Grimm, E. \& SchWarz, M. (I976b). Wechselwirkungen zwischen L-Aspartat und Kaliumionen beim Transport in die Zelle. Arzneimittel-Forschung 26, I $195-1201$.

RUdORF, J. (1971). Kinetische Untersuchungen zur Spezifität des aktive Transportes neutraler Aminosäuren bei Streptomyces hydrogenans. Thesis, University of Frankfurt, Federal Republic of Germany.

Schupp, T., HutTer, R. \& Hopwood, D. (1975). Genetic recombination in Nocardia mediterranei. Journal of Bacteriology 121, 128-136.

TANG, S. C. \& HowARD, D. H. (1973). Uptake and utilization of glutamic acid by Cryptococcus albidus. Journal of Bacteriology 115, 98-106.

Tempest, D. W., Meers, J. L. \& Brown, C. M. (1970). Influence of environment on the content and composition of microbial free amino acid pools. Journal of General Microbiology 64, I7I-I 85.

Wiley, W. R. \& MAtchetT, W. H. (1968). Tryptophan transport in Neurospora crassa Journal of Bacteriology 95, 959-966.

Wolfinbarger, L., Jervis, H. H. \& DeBusk, G. (197I). Active transport of L-aspartic acid in Neurospora crassa. Biochimica et biophysica acta 249, 63-68.

YABU, K. (I971). Aspartic acid transport in $M y c o-$ bacterium phlei. Japanese Journal of Microbiology r5, $449-456$. 